九州大学学術情報リポジトリ

Kyushu University Institutional Repository

Research Note on the Amitābha Cult and Its Imagery in Early Japan

SHIRAI, YOKO HSUEH

https://doi.org/10.5109/4377711

出版情報 : Journal of Asian Humanities at Kyushu University. 6, pp.93-111, 2021-03. Kyushu University, School of Letters, Graduate School of Humanities, Faculty of Humanities バージョン:

権利関係 : 


\title{
Research Note on the Amitābha Cult and Its Imagery in Early Japan
}

\author{
YOKO HSUEH SHIRAI
}

MAGINE a place inhabited by celestial musicians playing delightful music beside a beautiful, jeweled palace. There is a pond filled with lotus buds and flowers in full bloom, and nearby are verdant trees and countless divine beings who welcome you to their heavenly paradise. You - or to be precise, a reborn version of you, after your earthly life has come to an end-lack for nothing here. Everyone is guaranteed rebirth in this blissful paradise, located in the direction of the setting sun, simply by calling out the name of the One who presides here: Amitābha (Jp. Amida 阿弥陀). The Amitābha cult in Japan is generally considered to have emerged in the late Heian 平安 (ca. 1068-1185) or Kamakura 鎌倉 $(1185-1333)$ period. ${ }^{1}$ Yet the earliest Buddhist icons identified as Amitābha in Japan

\footnotetext{
Many thanks to the anonymous reader who helped reformulate sections of this essay. I am also grateful to Akiko Walley, who commented on an earlier draft (June 2018). Ideas appearing in this research note were first presented on 12 February 2016 at "Reassessing Kodai: An Interdisciplinary Workshop on Approaches to the Cultural History of Early Japan and its Historiography" at the University of Michigan, hosted by Professor Kevin Carr and his graduate students, Chun Wa Chan and Susan Dine. Anne McGannon, Sonya Lee, Fukuda Sayoko, Hirooka Takanobu, and Shimizu Akihiro kindly provided critical assistance. William Bodiford, as always, has patiently answered questions relating to this work. All errors remain the responsibility of the author.
}

reflect Hakuhō culture (Hakuhō bunka 白鳳文化, ca. 645-710), within the Asuka 飛鳥 (538-710) period, almost three centuries earlier. ${ }^{2}$ This unsatisfactory gap in knowledge is quite puzzling. Why have scholars been unable to reach a consensus regarding the exact nature of the Amitābha cult and its imagery in pre-eleventh century Japan?

After years of research on this topic, it has become evident to me that the state of the field itself prevents definitive clarification, due in part to the uneven nature of what was transmitted to and practiced on the Japanese islands, especially during the seventh and eighth centuries. The extant written and material evidence indicates that the earliest followers of Amitābha in Japan may not have consistently distinguished images of Amitābha from other buddha icons, in particular Maitreya (Jp. Miroku 弥勒), the Future Buddha. ${ }^{3}$ If this was

1 One well-regarded volume among many published in English is Payne and Tanaka, Approaching the Land of Bliss.

2 Breaking up the past into named periods such as the "Kamakura period" is a modern, scholastic artifact, and scholars may differ in the starting and ending dates they select for a given period. Regarding Hakuhō, see McCallum, Hakuhō Sculpture, pp. 15-17.

3 I do not discuss other buddhas, such as Bhaișajyaguru (Jp. Yakushi 薬師), the Medicine Buddha, in this research note because I observed a significant degree of overlap between Amitābha and Maitreya; however, there is a certain degree of 
indeed the case, we can speculate that the iconography of Amitābha (and perhaps Maitreya as well) was not yet standardized and that there were overlaps in the ritual use of these icons during the first few centuries after the seventh century. As in many fields of study, the dearth of surviving evidence, both material and written, has placed limits on secondary scholarship. In short, the presumed lack of consistency in practice during the first few centuries after the seventh century, combined with a lack of substantial records and evidence available to scholars in the twenty-first century, conveys an impression of overall ambiguity and unevenness with regard to the Amitābha cult and imagery in early Japan. This research note therefore seeks to contribute to the field by summarizing recent publications that offer insights into the Japanese Amitābha cult and its imagery based in part on new archaeological discoveries in Japan. My broader research has focused on the study of Amitābha, especially within events dating to the seventh and eighth centuries; this review focuses on recent secondary scholarship on Amitābha icons and other evidence from the seventh through the ninth century.

\section{Concerning Early Practice}

Two studies in particular have a bearing on the ambiguity in cultic practice during the Hakuhō and Nara 奈良 (710-784/794) periods. In his 2017 examination of prayer texts (Jp. ganmon 願文, Ch. yuanwen), Bryan Lowe corroborates the lack of standardization. "By the Nara period," Lowe writes, "patrons were readily conversant in the terminology of pure lands and heavens [associated with specific buddhas] that had only recently been introduced to Japan, as evidenced by the frequent appearance of Buddhist proper names in prayers." 4 These proper names included references to Amitābha's pure land, but "most common" at this time were "invocations of the future buddha Maitreya's Tuṣita heaven (Jp. tosotsuten 覍率天 or toshitaten 覩史

interchangeability between the pure lands of Amitābha and Bhaișajyaguru-a topic that deserves further study.

4 Lowe, Ritualized Writing, p. 74. Lowe explains that "[i]n the Nara period, prayers were most commonly performed on behalf of the deceased, asking that they be born in a better place such as a heaven or a pure land" (p. 61). For more in English on the Amitābha cult during the Nara period, see Rhodes, "The Beginning of Pure Land Buddhism in Japan." Many thanks to Cynthea J. Bogel for directing me to this article, among others.
多天).... From the evidence in prayers, we can conclude that these new cosmological ideas spread widely and rapidly in Japan and were well known by the mid-Nara

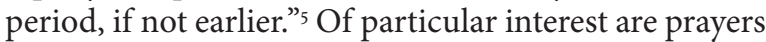
that demonstrate how "patrons creatively imagined the heavens and pure lands they invoked": some prayers expressed a wish for the spirit of the departed to travel to two separate buddha realms, a notion "unorthodox by canonical standards, though common in prayers." ${ }^{\circ}$ Lowe's work indicates several key developments in the Nara period: the Amitābha cult was rising in popularity but the Maitreya cult was more prevalent; ${ }^{7}$ the pure land or heaven of more than one buddha could be "creatively imagined" in "unorthodox" ways; and some devotees aspired to more than one heavenly paradise after death.

Many new ideas, including religious concepts like these, originated from the Chinese mainland and were then filtered through the Korean Peninsula before arriving on the Japanese islands. It is important to keep in mind that features that arrived intact from abroad are hard to distinguish from those that were invented or changed in Japan; each should be analyzed on a case-by-case basis. In terms of Amitābha's pure land, some of the ambiguity or unorthodoxy that we perceive may have existed since the cult's inception. In his study of the Chinese context, Robert Scharf argues for a revision of our idea about an independent Pure Land school, urging that we "abandon not only the notion of a distinctive and self-conscious Pure Land school comprised of an orthodox lineage of patriarchs, but also the idea of a distinctive Pure Land approach to Buddhist soteriology." ${ }^{8}$ Rather, "Pure Land cosmology and practice were part and parcel of Chinese Buddhism virtually from its inception." So although there were those who "specialized in Pure Land scriptures" or "lay persons whose devotions were centered on Amitābha and the aspiration for rebirth in his Pure Land, they did not constitute anything resembling an independent tradi-

5 Lowe, Ritualized Writing, p. 74. In the same paragraph, Lowe lists the various names for Amitābha's paradise: "Realm of Tranquility and Nourishment (Jp. An'yōkai 安養界), Land of Tranquility and Bliss (Jp. Anraku kokudo 安樂國土), or simply Supreme Bliss (Jp. Gokuraku 極樂)."

6 Ibid., pp. 74-75.

7 Lowe adds, "As numerous scholars have observed, the cult of Maitreya likely surpassed that of Amitābha in the eighth century." Ibid., p. 103; references for the "numerous scholars" appear in n. 50 on p. 103.

8 Scharf, "On Pure Land Buddhism," p. 319

9 Ibid., p. 320. 
tion, much less a school." ${ }^{\prime \prime}$ If the Amitābha cult was not really an independent cult or tradition in China during these centuries, as Scharf proposes, then it is likely that this was also the case in Japan. This helps explain the ambiguity or unorthodoxy that we perceive in the historical record.

\section{On the Origins of the Amitābha Image}

What did early images of Amitābha look like? To answer this question we need to examine the history of Amitābha belief in India and China.

The Amitābha cult arose in India, although details as to the precise location remain obscure. According to one textbook on Japanese Buddhism:

Very little is known regarding the inception of belief in either the Buddha Amitābha or his Western Pure Land (Sukhāvatī) in early India, and to date no hypothesis has won general acceptance. The earliest forms of the Larger Sukhāvatī-vyūha and Amitābha sutras both appeared during approximately the first century A.D. at the time of the Kuṣāna dynasty in northwestern India. ${ }^{11}$

There is, in my opinion, little doubt that written accounts of Amitābha preceded the imagery, although specific dates are not clear. It also seems clear that Amitābha literature and imagery developed separately, evolving along parallel but separate trajectories. Basic doctrines concerning Amitābha were written down in the Sukhāvatīvyūha, two canonical Mahāyāna texts that explain the significance of Amitābha and Sukhāvatī ("Land of Bliss" or "Pure Land"), the realm over which Amitābha presides. Known by several namesthe Larger Sukhāvatīvyūha Sutra (Jp. Muryōjukyō 無量寿経, Ch. Wuliangshou jing) and the Shorter Sukhāvatīvyūha Sutra or Amitābha Sutra (Jp. Amidakyō 阿弥陀経 $)^{12}$ - the scriptures tell us three things that

10 Ibid.

11 Both of these sutras mention Amitābha. Matsunaga and Matsunaga, Foundation of Japanese Buddhism, vol. 2, pp. 19-20. For the study of Amida, Fujita, Jōdo sanbukyō no kenkyū, is highly relevant.

12 For an English translation of the Sukhāvatīvyūha scriptures, see Gómez, The Land of Bliss. For a more recent translation of the Shorter Sukhāvatīvyūha sutra, see Gómez, "Rebirth in the Land are significant for Amitābha imagery. First, Amitābha is attended by two bodhisattvas: Avalokiteśvara (Jp. Kanzeon bosatsu 観世音菩薩 or Kannon 観音), often depicted with a miniature, seated buddha on the crown (Jp. kebutsu 化仏); and Mahāsthāmaprāpta (Jp. Seishi bosatsu 勢至菩薩), whose attribute is a long-necked bottle on the crown. ${ }^{13}$ Second, the inhabitants of Sukhāvatī "move freely, riding in seven-jeweled airborne palaces." And third, the process of rebirth involves being "spontaneously born by transformation, seated with legs crossed, in the seven-jeweled lotus flowers." ${ }^{44}$ That is, newborn souls emerge out of lotus flowers that grow in the ponds of Sukhāvatī.

A portion of the earliest surviving Amitābha sculpture was recovered in 1977 at Govindnagar, on the western outskirts of Mathurā City in India. According to Gregory Schopen, the inscription on the base contains "an unambiguous reference to the Buddha Amitābha" and a date, "the 26th year of the Great King Huveșka," which likely corresponds to the year 153 CE. ${ }^{15}$ Unfortunately, we do not know what the figure looked like as only the bare feet of this stone buddha remain. Schopen raises the possibility that almost as soon as the cult of Amitābha came into existence, Sukhāvatī became non-specific and non-exclusive to Amitābha, a phenomenon he describes as a "definite process of generalization and dissociation from Amitābha." Schopen believes his interpretation "may have isolated the key factor in the history of the development of the 'cult' of Amitābha in India": this generalization essentially "effected a decline and weakening of the specific cult of Amitābha as a separate entity" because it would have emptied the Amitābha cult of one of its signature offerings, namely rebirth in Sukhāvatī. ${ }^{16}$ So if the Amitābha cult did not become independent, popular, or dominant in India soon after its emergence, then there was probably no distinctive buddha image that exclusively depicted Amitābha.

of Bliss." Other translations are found in Inagaki, The Three Pure Land Sutras.

13 The names of the two bodhisattvas can be found in the English translation of the scripture by Inagaki, The Three Pure Land Sutras, p. 36, corresponding to Muryōjukyō, p. 273b.

14 Inagaki, The Three Pure Land Sutras, pp. 57-58, corresponding to Muryōjukyō, pp. 278a-b.

15 For monochrome reproductions of the image, see Schopen, "The Inscription on the Kuṣān Image of Amitābha," figure 1 on p. 249, and figures 2a-b on pp. 250-51.

16 Schopen, "Sukhāvatī as a Generalized Religious Goal," p. 183. 
Elizabeth ten Grotenhuis likewise believes the "cult" of Amitābha in India was "quite minor" and draws attention instead to the popularization of Amitābha in China:

\section{Whatever kind of Amidist movement existed seems to have been quite minor [in India] during the Kushan period (ca. 50-200 CE) and to have become submerged during the Gupta period (320-570). Not until the eighth century do Chi- nese pilgrims to India mention Pure Land practice. We must therefore look to China to observe the development of an early religious tradition focused on Amida. ${ }^{17}$}

Worship of Amitābha appears to have gained a foothold in China during a chaotic period that spanned more than three centuries, when China was not unified into a single empire. Referred to variously as the Period of Disunity, the Age of Fragmentation, the Six Dynasties, or the Northern and Southern Dynasties, this period began after the fall of the Han dynasty in 220 CE and ended with the reunification of China by the Sui in 589 $\mathrm{CE}$. This time of uncertainty could be viewed as providing fertile ground for the introduction and adaptation of new ideas from foreign sources, including belief in Amitābha. According to Eileen Hsu:

\section{Through the interpretation of scriptures and proselytizing efforts, Pure Land Buddhism gained increasing popularity in the fourth and fifth centu- ries, particularly in the south among members of the elite driven from northern China by the invad- ing nomads at the end of the Western Jin dynasty (265-317). Among the most influential Pure Land advocates was Huiyuan 慧遠 (334-416 or 417), who attracted enthusiastic gatherings in the cult center at Lushan, Jiangxi province. ${ }^{18}$}

Hsu begins her examination of the earliest surviving Amitābha images from China with the "statues of the Buddha Amitāyus and the bodhisattvas Avalokiteśvara and Mahāsthāmaprāpta," located in Niche 6 of Cave 169 in the Binglingsi 炳靈寺 cave complex in Gansu 甘蔗

\footnotetext{
17 Ten Grotenhuis, Japanese Mandalas, p. 19.

18 Hsu, "The Sengchou Cave and Early Imagery of Sukhāvatī," pp. 312-13.
}

Province and dated by inscription to $420 \mathrm{CE}$ (Western Qin kingdom, 385-431). ${ }^{19}$ The central buddha sits with legs crossed and the partially damaged hands rest in the lap. Without the inscription, it would be virtually impossible to identify the figure as Amitābha.

Hsu also discusses three relief images dated to the sixth century that depict Amitābha's paradise. The first, a stele excavated in 1953 at Wanfosi 萬佛寺 near Chengdu, Sichuan Province, and attributed to the Southern Liang dynasty (502-557), "best exemplifies the southern tradition of Pure Land imagery" and is one of the "earliest known representations of Sukhāvatī in China." ${ }^{\circ}$ In this paradise scene a small buddha, presumably Amitābha, is seated at the top of a triangular composition, accompanied by standing attendants, trees, a pair of two-story palaces, and a pond filled with what appear to be newly reborn souls among lotus flowers. Amitābha is not enlarged, so details such as the hand position are difficult to see.

Hsu's second relief was found in what is generally known as the Xiaonanhai 小南海 cave-temple in Anyang 安陽 County, Henan 河南 Province, dated to between 555 and 560 (Northern Qi dynasty, 550-577). ${ }^{21}$ (Hsu refers to this as the "Sengchou cave" after its sponsor, the eminent monk Sengchou 僧稠 [48o-56o].) On the west wall, above the haloes of the standing Buddha triad, is a scene in low relief that portrays Sukhāvatī. Oddly, a buddha is nowhere to be found in the scene. Nevertheless, newly reborn souls sit inside lotus flowers, and behind the blooms are trees and palace buildings. Most critically, and "unprecedented in Buddhist art before Sengchou's time, [are] the multiple cartouches inscribing the various categories of rebirth and scenes of Sukhāvatī described in the Guanjing 観経” (Ch. Foshuo Guan wuliangshoufo jing 仏説観無量寿仏経, the Scripture Spoken by the Buddha on Visualizing the Buddha of Immeasurable Life). ${ }^{22}$ The cartouches

19 Ibid., p. 312 and figure 13. In n. 65 on p. 309, Hsu indicates that the two names, Amitāyus, or "Buddha of Immeasurable Life" (Ch. Wuliangshoufo 無量寿仏), and Amitābha, or "Buddha of Boundless Light" (Ch. Amituofo 阿弥陀仏), were "often used interchangeably"; Hsu, too, seems to use the names interchangeably in her article.

20 Ibid., p. 313 and figure 14 .

21 Ibid., p. 309 and figures 11-12. The cave's principal sculptures are missing their heads and some of their hands, so the reliefs carved on the walls, which were spared from damage, provide the best examples for study.

22 Ibid., pp. 310, 316. On p. 311, Hsu states that the "Guanjing was translated in the middle of the fifth century by the Central Asian 
are inscribed with labels indicating the Nine Degrees of Rebirth, such as "middle rebirth of the upper rank." According to Hsu the insertion of cartouches to identify the various degrees or ranks associated with rebirth in Amitābha's paradise is a "Chinese interpolation" or invention. ${ }^{23}$ Portraying and then inscribing each rank in the relief image of Sukhāvatī thus reflects "the early development of a sinicized Pure Land Buddhist art." ${ }^{24}$ These modifications likely signify attempts to make the Amitābha cult more appealing and familiar to potential donors in sixth-century China.

Hsu's third Sukhāvatī relief was removed from a limestone cave-temple and is now housed at the Smithsonian Institution's Freer Gallery of Art in Washington, D.C. ${ }^{25}$ The relief is attributed to Cave 2 of the Nan 南 (south) Xiangtangshan 響堂山 monastery complex in Hebei 河北 Province, an array of cave-temples created in the Northern Qi around $565 \mathrm{CE}$, or approximately one decade after the Sengchou cave. ${ }^{26}$ The central buddha in the relief sits under a jeweled canopy with legs crossed, right hand raised with open palm facing the viewer, left hand resting in the lap. There is a pair of miniature, palace-like buildings on the far right and left of the relief, and in a small rectangular pool in front of Amitābha are several newly reborn souls seated on lotus flowers. The sculptural styles and trends established at Xiangtangshan not only continued into the Sui dynasty,

monk Kālayaśas (Ch. Jiangliangyeshe 畺良耶舎)." See Foshuo Guan wuliangshoufo jing.

23 "This hierarchical system of rebirth, not found in either the Larger or the Shorter Sukhāvatīvyūha Sutra, provided the rationale for further development of Pure Land devotion aimed at achieving the vision of Amitāyus through meditation as the sole means to rebirth in Sukhāvatī.... Especially significant is that the theme of the Nine Degrees of Rebirth is arguably a Chinese interpolation, absent from the original Sukhāvatī [vyūha] scriptures." Ibid., pp. 314-15.

24 lbid., p. 309

25 Ibid., figure 15. Hsu labels the Freer relief as "Purchase, F1921.2." For a digital image, see https://asia.si.edu/object/F1921.2/.

26 The Sengchou cave and the groups of caves known as Nan Xiangtangshan and Bei 北 (north) Xiangtangshan are relatively close to one another. The northern and southern sites in Xiangtangshan are roughly fifteen kilometers apart (Tsiang, Echoes of the Past, p. 18), while the Sengchou cave lies about fifty kilometers from Xiangtangshan (Steinhardt, "Xiangtangshan and Northern Qi Architecture," p. 64). Because Sengchou was the chief abbot of the Bei Xiangtangshan monastery complex near Ye (present-day Lin'an 臨安 County, Hebei Province), the capital of the Northern Qi kingdom, Hsu considers it likely that a close relationship existed between these sets of cave-temples. See Hsu, "The Sengchou Cave and Early Imagery of Sukhāvatī," p. 290. but were disseminated to regions beyond China, for instance the Japanese archipelago, as Katherine Tsiang has persuasively argued. In her examination of imagery from Xiangtangshan, Tsiang offers several important considerations about this context. First, contrary to how the Xiangtangshan caves are generally perceived today, in conception and patronage they were not unified but instead were associated with different monasteries. ${ }^{27}$ Second, most of the imagery was removed and taken to museums around the world. And third, although the Northern Qi dynasty lasted only twenty-eight years, "its impact on the history of Chinese art is disproportionately large [and] the art of [the Northern Qi] was a model for that of subsequent periods." ${ }^{28}$

The Xiangtangshan caves contain commissioned images of various buddha icons, and among these Tsiang identifies the three most likely Amitābha groupings (in addition to the Freer relief mentioned above) as follows:

1. Northern Xiangtangshan, South Cave, East wall altar: a large, headless buddha seated with right leg crossed over the left, whose hands are either missing or damaged. The buddha is joined by six standing attendants with missing heads. Based on old photographs of the icons with intact heads, Tsiang identifies two of the four standing bodhisattvas as Avalokiteśvara and Mahāsthāmaprāpta, suggesting that the buddha in the center was Amitābha. ${ }^{29}$

2. Southern Xiangtangshan, Cave 2: a pair of freestanding, greater than life-size limestone sculptures, believed to be from this cave and now in the University of Pennsylvania Museum of Archaeology and Anthropology. One is identified as Avalokiteśvara based on the small buddha image in the crown. The second may be Mahāsthāmaprāpta, but this attribution is less definitive..$^{30}$ They likely formed a triad whose central buddha was Amitābha.

3. Southern Xiangtangshan, Cave 4 (one of three caves situated directly above Cave 2): three seated figures in the round, originally at the back wall, joined by two free-standing icons. The figural group no longer remains in situ but an inscription carved into the back wall "identif[ies] these [free-standing

27 Tsiang, Echoes of the Past, p. 18.

28 Ibid., p. 19.

29 Ibid., figure 19 on p. 37, pp. 38-39.

30 lbid., figures $20-21$ on pp. 204-207. 
sculptures] as the bodhisattvas Avalokiteśvara and Mahāsthāmaprāpta." ${ }^{31}$ This raises the possibility that the central buddha was Amitābha.

\section{Amitābha Images in Japan}

As the above examples make clear, exactly what the image of Amitābha looked like, or should look like, was not yet fully developed in sixth-century China. Researchers must rely on inscriptions or circumstantial evidence to confirm an icon's identity: Amitābha accompanied by the bodhisattvas Avalokiteśvara and Mahāsthāmaprāpta, or Amitābha represented in a scene that includes palace buildings and a lotus pond with reborn souls. Although these features can be used to identify Amitābha in Chinese imagery, this is rarely the case for the earliest icons found in Japan. Inscriptions do not exist for most images and, with few exceptions, the narrative framework of a palace and reborn souls is not found. The primary indicator of Amitābha has thus been the identification of the two attendants Avalokiteśvara and Mahāsthāmaprāpta in a buddha triad. Some art historians, primarily those working in Japan, have attempted to identify single and unaccompanied buddha icons - presumably the lone survivor from a group of sculptures - based on iconographic or visual clues. But traditions for making buddha icons were still being formed during this period in Japan, so relying on iconography as a means to identify these images is of limited use. Nonetheless, some of these studies have gained wide acceptance, so a review of the relevant publications is warranted.

Okada Ken has established an iconography for Amitābha images dating primarily to the seventh and eighth centuries based on a visual device found in confirmed images of Amitābha icons of the same period from China. ${ }^{32}$ According to Okada, sponsorship of Amitābha images in China, as identified by inscription, gained in popularity during the second half of the sixth century, ${ }^{33}$ though initially, images of Amitābha were indistinguishable from other icons such as Sākyamuni. Various buddhas were depicted with the dharmacakra

31 Ibid., p. 45.

32 Okada, "Shotōki no Tenpōrin'in Amida zuzō ni tsuite no kenkyū."

33 Ibid., p. 21. Okada refers to an inscribed date which corresponds to 588 CE on a white jade icon unearthed in Quyang 曲陽, Hebei Province. mudrā - a hand gesture in which the tips of two fingers on one hand touch to make the shape of a wheel, known as the teaching gesture. But at some point after the Sui period, the dharmacakra mudrā was appropriated to create a "new" dominant image of Amitābha in China that looked suitably foreign or Indian. Okada proposes that this type of Amitābha image did not previously exist in India or Central Asia, but was invented in China. ${ }^{34}$ One well-preserved mural painting dating to 642 on the south wall of Cave 220 at Mogao, Dunhuang, features a seated Amitābha whose fingers are positioned in the dharmacakra mudrā. ${ }^{35}$ As this specific image-type of Amitābha became increasingly popular in China, it was soon transmitted across the sea and reached the Japanese islands by the second half of the seventh century.

Nakano Satoshi, who has studied the Amitābha cult in Nara Japan, ${ }^{36}$ reinforces Okada's claim that the dharmacakra mudrā serves as a visual indicator of Amitābha during a limited period in Japan. But he proposes an even more specific categorization since Okada did not specify exactly which fingers should touch to form the wheel gesture. Nakano establishes a stylistic evolution among images presumably manufactured in Japan and identifies a tradition dating to the Hakuhō period that features an Amitābha whose thumb is joined to the index or middle finger on each hand in what he calls the "Hakuhō style." Then a shift occurred in the subsequent Nara period: this "Nara style" has Amitābha joining the thumb with the ring finger. Nakano believes the Nara-style hand gesture was an intentional innovation, an attempt to create a more orthodox image by replicating a written description of Amitābha in Darani jikkyō 陀羅尼集経 (Ch. Tuoluoni jijing), a scripture known to have circulated at the highest levels of court during the eighth century. It is important to note, however, that the older, Hakuhō-style hand gesture continued to be used

\footnotetext{
34 Ibid., p. 29. This process of "sinicization" was not limited to images of Amitābha, but reflects a broader trend in Chinese Buddhism during this period. Mizuno Saya finds a similar phenomenon taking place in the visual representation of Divinities of the Eight Classes (Jp. tenryū hachibu shū 天竜八部衆, Ch. tianlong babu 天竜八部). According to Mizuno, selected divinities of both local and foreign origin were incorporated into the Divinities of the Eight Classes around the second half of the sixth century in China. See Mizuno, "Hachibushūzō no seiritsu to hirogari," p. 198

35 For a color reproduction of Amitābha in Cave 220, see Lee, Surviving Nirvana, figure 3.29, p. 172. 36 Nakano, Nara jidai no Amida nyoraizō to Jōdo shinkō.
} 
for some images dating to the Nara period.

\section{The Hakuhō Style}

In the following artworks, Nakano identifies the central buddhas as Amitābha based on their "Hakuhō-style" hand gesture - the thumb touching the index or middle finger of the same hand:

1. Figured Buddhist tiles: These are referred to in the Japanese secondary literature as senbutsu 㙛仏, and multiple fragments have been excavated from the ruins of the Buddhist temples Natsumi Haiji 夏見廃寺 in Mie Prefecture and Nikōji Haiji 二光寺廃寺 in Nara Prefecture. ${ }^{37}$ The tiles are attributed to the late seventh and early eighth centuries.

2. Hōryūji Kondō hekiga rokugōheki 法隆寺金堂壁画 六号壁 (Hōryūji Golden Hall mural no. 6): The execution of the mural is attributed to the end of the seventh or the beginning of the eighth century..$^{38}$

3. Taima mandara 当麻曼荼羅: This tapestry, housed at Taimadera in Nara Prefecture, is described by Elizabeth ten Grotenhuis as "[o]ne of the most important types of Pure Land mandara in Japan." ${ }^{39}$ Both ten Grotenhuis and Nakano indicate that it was manu- factured during the eighth century in China. ${ }^{40}$ At the earliest, this tapestry could have arrived in Japan during the Nara period, perhaps in the second half of the eighth century. As a Chinese work, this image fits well with the standard portrayal of Sukhāvatī in Tang imagery. This Sukhāvatī scene, with its elaborate palace structures and pond with reborn souls, is rare among surviving eighth- and early ninth-century representations of Amitābha in Japan. Yet the existence of Taima mandara gives rise to an interesting possibility: that images of Sukhāvatî could have been represented at Nara temples. This notion is supported by green-glazed tile fragments unearthed during archaeological surveys. Decorated with wave designs indicating ripples on the surface of a pond, these tiles may have been used to compose a three-dimensional, sculptural scene of Sukhāvatī with a life-size Amitābha icon. This body of material evidence will be discussed below.

4. Zutō 頭塔 triad: Located in Nara City, the monumental earth and stone pyramidal pagoda is dated to the late eighth century and features a triad carved in low relief in stone on the exterior surface. According to Nakano's thesis, the relief is an example of the now old-fashioned Hakuhō style still being employed during the Nara period. ${ }^{41}$

\section{The Role of Darani jikkyō}

The Buddhist scripture Darani jikkyō, mentioned above, contains detailed visual descriptions of Buddhist deities such as Amitābha and may therefore have had a direct influence on the production of new Amitābha imagery in Nara Japan. Darani jikkyō (Collected Dhāraṇi Sutras) is, according to Koichi Shinohara, a twelve-

40 Ten Grotenhuis, Japanese Mandalas, p. 3; Nakano, Nara jidai no Amida nyoraizō to Jōdo shinkō, p. 299. According to Nakano, earlier scholars proposed that the Taima mandara was manufactured in Japan during the Nara period, but today it is believed to have originated in Tang China. Nakano's n. 17 refers to Ōta (1963), "Tsuzure ori Taima mandara ni tsuite." In a reprint, Ōta states that the Taima mandara was probably not made in Japan, and was instead brought over from Tang China. See Ōta (1978), "Tsuzure ori Taima mandara ni tsuite."

41 See Nara Kokuritsu Bunkazai Kenkyūjo, Shiseki Zutō hakkutsu chōsa hōkoku, pls. 33, 73. For a brief discussion of Zutō, see Nakano, Nara jidai no Amida nyoraizō to Jōdo shinkō, pp. 293-302. Additional information is available online at http://www.pref .nara.jp/6709.htm. 
volume compilation of various documents..$^{42}$ The Sanskrit word dhāranī (Jp. darani 陀羅尼) can be translated as "spells"; these were often chanted and believed to have a magical component. ${ }^{43}$ Cynthea J. Bogel describes Darani jikkyō as "an influential esoteric work consisting of assembled esoteric rituals and sutras ... [that was] known in Japan by Tenpyō 天平 9 (737)." ${ }^{44}$ Indeed, records dating to the mid-eighth century from the Offices of Queen Consort Kōmyō (also known as the Queen Consort's Palace Agency) include written requests to borrow Darani jikkyō, indicating the availability and significance of this set of scriptures during this time. ${ }^{45}$ Kōmyō kōgō 光明皇后 (701-760) was Queen Consort to the Heavenly Sovereign, Shōmu tennō 聖武天皇 (701-756, r. 724-749), and there is growing evidence that she was involved in the incipient Amitābha cult, primarily because of her association with the most important temples of this time: Tōdaiji, Hokkeji 法華寺, and Hōryūji.

Given that Darani jikkyō was available in Nara Japan, Nakano believes the text served to instruct and guide

42 The full title is Foshuo tuoluoni jijing fanyi $x u$, p. 785a, but in the Japanese secondary literature the title is often shortened to $D a$ rani jikkyō. According to Shinohara, the collection was compiled in the mid-seventh century by Atikūța, an Indian monk from central India. Furthermore, "the name of the translator, given in transcription as Adiquduo 阿地䨉多, is elsewhere translated as Wujigao 無極高." See Shinohara, Spells, Images, and Mandalas, pp. 28-29, and note 2 on p. 238. Brief mention of this scripture also appears in Orzech, "Ritual Subjects," pp. 269, 278. A classic study in Japanese is Sawa, "Darani jikkyō oboegaki."

43 For an extensive investigation, see Copp, The Body Incantatory. In his preface on p. xx, Copp argues that dhāranii were part of an "ancient heritage of protective magic" and were "important parts of Buddhism in China for at least five hundred years before proponents of the 'Esoteric synthesis' begin to establish their lineages there in the early eighth century." Copp briefly discusses Tuoluoni jijing (Jp. Darani jikkyō) and defines "esoteric" in his n. 14 on p. 291.

44 Bogel, With a Single Glance, p. 28. Bogel refers to Ishida, Shakyō yori, n. 39 on p. 358. Seyama Satoshi also claims that in 1930 Ishida Mosaku was the first to state that Darani jikkyō was mentioned in Japanese records corresponding to 737 CE. Seyama, "Darani jikkyō yō Shitennōzō no Nihon ni okeru juyō to tenkai," p. 83.

45 See the following Shōsōin documents: DNK Hennen 13, "Shibi chūdai shōkyōmon" 紫微中台請経文, Tenpyō Shōhō 天平勝宝 7 (755).8.21 (pp. 154-55); DNK Hennen 4, "Kyōsho suitōchō" 経疏出 納帳, Tenpyō Shōhō 7 (755) (pp. 85, 91-92); and DNK Hennen 12, "Shakyō bujō chūmon" 写経奉請注文, Tenpyō Shōhō 5 (753).5.1 (p. 440). Digitized documents are accessible at http://wwwap .hi.u-tokyo.ac.jp/ships/shipscontroller by selecting the database for Nara-period Ancient Manuscripts (奈良時代古文書フルテキスト データベース). For a discussion of these entries, see Nakano, Nara jidai no Amida nyoraizō to Jōdo shinkō, pp. 132, 195-97, 257-61. image-makers on what Amitābha should look like, perhaps to maximize ritual effectiveness. ${ }^{46}$ According to Darani jikkyō, an image of Amitābha consists of a seated buddha with legs crossed and each foot resting on the opposite thigh (kekka fuza 結加跌座), while both hands make the shape of a wheel (the teaching gesture, seppoin 説法印) with the tip of the thumb (oyubi 大指) touching the tip of the ring or fourth finger (mumeishi 無名指). ${ }^{47}$ Nagaoka Ryūsaku, too, has examined Amitābha images dating to the Nara and Heian (794-1185) periods, but in stark contrast to Nakano, who discusses Darani jikkyō over several chapters, Nagaoka mentions the compilation only once, in a footnote. ${ }^{48}$ Although Nagaoka's reasons for giving just a passing reference to Darani jikkyō are unknown, this opens up the possibility that Nakano may have been overly enthusiastic in relying so heavily on Darani jikkyō.

At least two other articles weigh in against Nakano's scholarship in general. Seyama Satoshi analyzes the reception and development of the Four Heavenly Kings (Deva) of Buddhism (Shitennō 四天王) and compares the extant imagery to descriptions found in Darani jik$k y \bar{o}$, or what Seyama calls "Darani jikkyō style" (Darani jikkyō yō 陀羅尼集経様). In contrast to earlier studies, Seyama concludes that in the case of the Four Heavenly Kings icons in Japan there was a time lag, and that the Darani jikkyō style was not employed by artists until the end of the eighth century, i.e. the beginning of the

46 The first scholar to name Darani jikkyō as a possible source for Amitābha depictions during the eighth century appears to be Mizuno Keisaburō; he is credited by both Nakano and another scholar, Nagaoka Ryūsaku. See Nakano, Nara jidai no Amida nyoraizō to Jōdo shinkō, pp. 183, 189; Nagaoka, "Amida zuyō no keishō to saisei," n. 37 on p. 298; and Mizuno, "Amida sanzonzō Denpōdō Nishinoma shozai," p. 69. A reprint with additional commentary is Mizuno, "Hōryūji Denpōdō no Amida sanzonzō sangu"; on p. 125 the author refers to the thumb and middle finger touching, but this appears to be a typographical error because it is the thumb and ring finger that touch in the Hōryūji Denpōdō Nishinoma icon; moreover, when Mizuno revisits the same icon on p. 128, he correctly mentions the thumb and ring finger.

47 Darani jikkyō, p. 8ooc. Nakano, Nara jidai no Amida nyoraizō to Jōdo shinkō, pp. 183, 194, 230, 296-99.

48 Nagaoka, "Amida zuyō no keishō to Saisei," n. 37, p. 298, writes that Mizuno observed the basis for the hand gestures in the second volume of Darani jikkyō. As to possible reasons for this short reference to Mizuno, perhaps Nagaoka was unconvinced that Darani jikkyō was the source for the hand gestures but chose not to refute Mizuno; perhaps he simply accepted Mizuno's attribution and saw no need for further elaboration; or, as suggested by this journal's anonymous reader, Nagaoka chose to emphasize his own theories instead of highlighting another scholar's work. 
Heian period. ${ }^{49}$ Although Seyama's thesis concerning the Four Heavenly Kings imagery may not apply to Amitābha icons, his findings serve as a precautionary note: just because Darani jikkyō was in circulation during the first half of the eighth century does not mean it was immediately appropriated for icon production. Ōkusa Hiroshi, too, takes issue with several theories in Nakano's monograph, arguing in one instance that Nakano misunderstood a primary source and thereby misinterpreted the relationship between Queen Consort Kōmyō and the monk Chikō 智光 (d.u.). Ōkusa also refutes the significance and meaning of rosaries, a core part of Nakano's argument. ${ }^{50}$

With such caveats in hand, we now proceed to the images assumed to represent Amitābha with the thumb and ring finger touching, discussed by Nagaoka and Nakano. Nagaoka examines surviving paintings and sculptures dating to the Nara period and later and identifies the following works:

1. Konbuin 興福院, Hōrenchō 法連町, Nara City: a wood-core dry lacquer icon dated to the second half of the eighth century (late Nara period)..$^{51}$

2. Private collection: a painting on silk, Kōfukuji kōdō mandarazu 興福寺講堂曼茶羅図, attributed to the "medieval period" (chūsei 中世), circa late twelfth to late sixteenth century. The Amitābha icon portrayed in this temple scene (of Kōfukuji 興福寺 in Nara City) may date to the eighth century. ${ }^{52}$

3. Kōryūji 広隆寺, Kyoto: a wood-core dry lacquer icon dated to the first half of the ninth century. ${ }^{53}$

4. Fushimiji 伏見寺, Kanazawa City, Ishikawa Prefecture: a small, gilt-bronze icon (H. $21.5 \mathrm{~cm})$ dated to the ninth century. ${ }^{54}$

5. Hokkeji 法華寺, Nara City: a painting on silk, Kenpon chakushoku Amida sanzon oyobi dōji zō 絹本著 色阿弥陀三尊及童子像 (Amida Triad With a Boy

\footnotetext{
49 Seyama, "Darani jikkyō yō Shitennōzō no Nihon ni okeru juyō to tenkai," pp. 82, 88.

50 Ōkusa, "Nara jidai Jōdo shinkōron no saikentō," pp. 234-35. I am grateful to Bryan Lowe for bringing this article to my attention.

51 Nagaoka, "Amida zuyō no keishō to saisei," pp. 288-90. For a reproduction, see NBZ 4, monochrome plate 89 on p. 140.

52 Nagaoka, "Amida zuyō no keishō to saisei," pp. 288-94, nn. 36 and 57. A cropped image of the Buddha appears as figure 2 on p. 289

53 Ibid., pp. 288-89. For a reproduction, see NBZ 5, figure 55

54 Nagaoka, "Amida zuyō no keishō to saisei," pp. 288-89. For a reproduction and the height of the Fushimiji icon, see NBZ 5 , monochrome plate 193 on pp. 143, 236.
}

Attendant), dated to the Heian period. ${ }^{55}$

Nagaoka proposes that this group of images reflects the creation of a specific Amitābha image-type, and attempts to connect this type to a specific historical event: the one-year death anniversary in 761 of Queen Consort Kōmyō..$^{56}$ While it is known that Queen Consort Kōmyō sponsored numerous Buddhist projects, the connection suggested by Nagaoka cannot be confirmed. As Nakano Satoshi explains, Nagaoka attempts to resurrect or reimagine Amitābha icons referenced in primary documents from the eighth century, yet their exact hand gestures remain unknown because visual descriptions of the icons were not provided in those documents and none of the icons mentioned are known to survive. ${ }^{57}$ The historical record does indicate that new Amitābha icons were commissioned to commemorate the death anniversary, but there is no way to validate Nagaoka's claim due to a lack of evidence. Nevertheless, I find it conceivable that an Amitābha image-type based on Darani jikkyo was created in the late Nara or early Heian, whether under Kōmyō's direction (if the image was made during her lifetime) or in memory of Kōmyō (if it was made after her death).

For his list of "Nara-style" Amitābha icons based on Darani jikkyō, Nakano refers to the five works identified by Nagaoka ten years earlier and then adds three more sculptures dating to the late Nara period. These icons are housed inside two temples located in Nara Prefecture-Hōryūji 法隆寺 and Saidaiji 西大寺:

6. Hōryūji Denpōdō 伝法堂 (East Precinct of Hōryūji): a hollow, dry lacquer icon, part of the "West Sector" (Nishi no ma 西の間) triad..$^{58}$

7. Hōryūji Denpōdō: a wood-core, dry lacquer icon, part of the "East Sector" (Higashi no ma 東の間) triad. 59

8. Saidaiji: a wood-core, dry lacquer icon, one of the "Buddhas of the Four Directions" (Shibutsu zazo 四仏座像). ${ }^{60}$

55 Nagaoka, "Amida zuyō no keishō to saisei," pp. 288-89. A color reproduction of the painting is available on the Hokkeji website at https://hokkejimonzeki.or.jp/about/treasure/.

56 Nagaoka, "Amida zuyō no keishō to saisei," with special emphasis on p. 280.

57 Nakano, Nara jidai no Amida nyoraizō to Jōdo shinkō, pp. 189-92.

58 Ibid., pp. 184-96, 230. For a reproduction, see NBZ 4, figure 76, monochrome plate 61 on p. 137.

59 Nakano, Nara jidai no Amida nyoraizō to Jōdo shinkō, pp. 190-93, 230. For a reproduction, see NBZ 4, figure 83 .

60 Nakano, Nara jidai no Amida nyoraizō to Jōdo shinkō, pp. 191-94, 230. For a reproduction, see NBZ 4, monochrome plate 87 on $\mathrm{p}$. 
These three images largely conform to the iconographical features detailed in Darani jikkyō for an Amitābha icon, but whether they were indeed commissioned as Amitābha cannot be confirmed. ${ }^{61}$ I find it possible that some Amitābha icons with the hand gesture of thumb and ring finger forming a circle were made during this period; yet it is equally possible that other buddhas, such as Maitreya, were likewise portrayed making the same hand gesture - an example of overlapping iconographical features. Sorting out questions of identity is a complex task for scholars today, but for the Naraperiod devotees who prayed to what they considered to be an Amitābha (or other buddha) icon, these iconographical concerns probably did not matter. ${ }^{62}$

\section{Archaeological Remains: Wave-Pattern Tiles}

Let us return to Taima mandara, the woven tapestry discussed above that portrays an image of Sukhāvatī. The existence of this tapestry suggests that there may have been other images of a pure land in eighthcentury Japan. One type of material evidence, known as "green-glazed wave-pattern tiles" (ryokuyū hamonsen 緑釉波紋塼 or ryokuyū suihamonsen 緑釉水波文塼), gives rise to the possibility that glassy ponds were represented in paradise scenes, perhaps even a version of the Sukhāvatī that is portrayed in Taima mandara. Yet we cannot simply assume that the tiles were linked to a (now lost) image of Sukhāvatī and Amitābha: they may just as well have been part of a paradise scene featuring Maitreya or Bhaisajyaguru during the seventh and eighth centuries in Japan. ${ }^{63}$ In other words,

140. A color image is available on the Saidaiji website at: http://saidaiji.or.jp/treasure/to4/.

61 The problem of identification is challenging because icons are often moved and transferred from their original place of installment. The Buddhas of the Four Directions at Saidaiji, for example, may have changed places or even been replaced by icons originating from other temples. As for the three sets of buddha triads housed inside the Hōryūji Denpōdō, one, two, or all three could have been donated from other temples.

62 Especially at this time in Japan, the requirements or expectations for "correct" Amitābha iconography were likely much less rigorous than in later periods. For a classic study on Amitābha icons in Japan, see Mitsumori, Amida nyoraizō.

63 Ōwaki examines wave-pattern tiles used to represent lotus ponds in Amitābha, Maitreya, or Bhaișajyaguru paradise scenes in Ōwaki, "Dōnai sōgon no kōkogaku," p. 17. For his other references to Bhaișajyaguru, see pp. 24-26. Glazed tiles without wave patterns may have been used as sacred decoration inside the portrayal of a pond was not exclusive to images of Amitābha's pure land during this period. Here is yet another instance of overlap in practice and imagery between different buddhas.

Since broken fragments of wave-pattern tiles tell us nothing about what the complete scene once looked like, scholars often consider the iconography of the Tachibana shrine (Tachibana fujin zushi 橘夫人厨子), which is stored at Hōryūji. Housed inside this miniature shrine is a gilt-bronze Amitābha triad with a bronze screen and base (Tachibana bunin nenjibutsu 橘夫人 念持仏), attributed to the late seventh or early eighth century. Cast on the flat surface of the bronze base are stylized wave patterns and lotus plants representing the surface of a lotus pond. ${ }^{64}$ Growing out of the base are three bronze stems in the round that support three large lotus flowers. Each flower in turn serves as a pedestal for one of the icons of the Amitābha triad - two standing bodhisattvas and one seated buddha. The waves on the base are styled in the form of neatly compartmentalized packets, somewhat resembling the shape of a peapod that encloses a tiny, undulating wave. Although none of the recovered tiles exhibit a similarly stylized wave shape, the Tachibana shrine demonstrates one way in which wave patterns were used in pure land scenes and opens the possibility that glazed tiles featuring a wave pattern were affixed on the base of a large icon or triad housed inside a special hall at a Nara temple.

\section{Wave-Pattern Tiles from Kawaradera and Kōfukuji}

Wave-pattern tile fragments have been unearthed at nearly a dozen archaeological sites dating to the seventh and eighth centuries, most of them within the former Nara or Heijō capital, though some were found in the surrounding regions. Ōwaki Kiyoshi provides a useful survey of these fragments. ${ }^{65}$ Three different

the Hokkeji Golden Hall, whose main icon is conjectured to have been Vairocana (Jp. Dainichi 大日). See ibid., pp. 29-30; Takahashi, "Sansai, ryokuyūsen sairon," p. 50; and Nakagawa, "Hokkeji kyūkeidai shutsudo kokusenmon nisaisen ni tsuite." The Nakagawa reference is available at http://repository.nabunken .go.jp/dspace/handle/11177/6788.

64 For a reproduction of the Tachibana shrine's bronze base, see McCallum, The Four Great Temples, figure 3.20 on p. 187.

65 Ōwaki, "Senbutsu to ryokuyū hamonsen ni yoru sōgon." The exhibition catalogue in which this article appears can be difficult 
types of wave-pattern tiles were unearthed from the ruined Buddhist temple Kawaradera 川原寺 and its environs in Nara Prefecture. ${ }^{66}$ Ōwaki indicates, however, that they were not necessarily installed when Kawaradera was first built in the seventh century; instead, he suggests the different types of tiles likely belonged to separate miniature shrines or pedestals for icons that were donated to Kawaradera between the seventh and eighth centuries. ${ }^{67}$ Based on his chronological sequence, Ōwaki proposes that one type of Kawaradera green-glazed wave-pattern tile, which dates to the end of the seventh century, is likely the oldest used in Japan. ${ }^{68}$ Next in his chronology is the bronze base with wave patterns in the Tachibana shrine at Hōryūji. The other two types of wave-pattern tiles discovered in and around Kawaradera probably date to the eighth century (figure 1). ${ }^{69}$

Ōwaki makes no further assessments about how the Kawaradera wave-pattern tiles may have been employed or in which structure, but more than a decade earlier, Takahashi Teruhiko proposed that these tiles were used to portray a narrative scene of the pure land of Maitreya-not Amitābha-in the temple's Central Golden Hall..$^{70}$ Takahashi bases this proposal on similarities he has identified between the Kawaradera Central Golden Hall and the Kōfukuji Central Golden Hall. An active temple today, Kōfukuji is located just south of the massive Tōdaiji 東大寺 temple complex in Nara City. That Kofukuji has survived into the present day is due in part to its role as the family temple of the

to locate; it is listed at http://www.worldcat.org/oclc/914461314. For a chart of glazed, wave-pattern tile fragments and relevant details such as excavation site and proposed manufacture date, see Ōwaki, "Dōnai sōgon no kōkogaku," p. 27.

66 For a discussion of Kawaradera see Shirai, "The Buddha Triad Senbutsu Unearthed in Japan," pp. 191-213. More extensive discussion appears in McCallum, The Four Great Temples, pp. 155-200.

67 Ōwaki, "Senbutsu to ryokuyū hamonsen ni yoru sōgon," p. 48. For an explanation in English, see McCallum, The Four Great Temples, pp. 185-87; in his note 62 on p. 186, McCallum cites Ōwaki, "Kawaradera," pp. 132-33.

68 For a reproduction of the Kawaradera wave-pattern tiles attributed to the seventh century, see Ōwaki, "Senbutsu to ryokuyū hamonsen ni yoru sōgon," p. 48; and McCallum, The Four Great Temples, lower photo of figure 3.19 on p. 186.

69 Ōwaki, "Senbutsu to ryokuyū hamonsen ni yoru sōgon," p. 51; a color reproduction of the tile fragments appears on p. 23. A monochrome image appears in McCallum, The Four Great Temples, upper photo of figure 3.19 on p. 186.

70 Takahashi, "Butsuzō sōgon toshiteno ryokuyū suihamonsen," p. 134 .

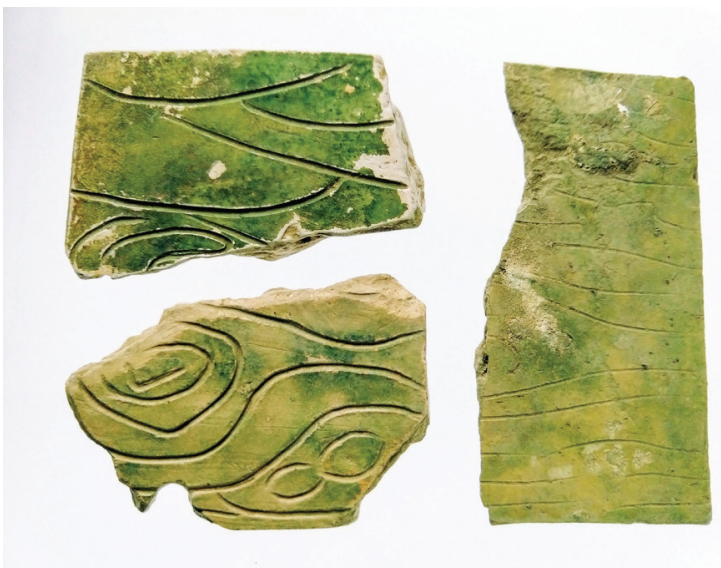

Figure 1. Wave-pattern tile excavated at Kawaradera Urayama Iseki 川原寺裏山遺跡, Nara Prefecture. 8th c. H 25, W 15.5, D $1.2 \mathrm{~cm}$. Housed at Asukamura Kyōiku li'nkai 明日香村教育委員会. From Ōwaki, "Senbutsu to ryokuyū hamonsen ni yoru sōgon," p. 23, lower photo; p. 47 for tile dimensions. Permission of Asukamura Kyōiku li'nkai and Nara Bunkazai Kenkyūjo Asuka Shiryōkan.

powerful Fujiwara 藤原 clan, which included such notable figures as Queen Consort Kōmyō, her father, Fujiwara Fuhito 藤原不比等 (659-720), and her mother, Agata Inukai Michiyo 県犬養三千代 (also known as Tachibana Michiyo 橘三千代, d. 733)..$^{71}$ Different types of wave-pattern tiles were unearthed near Kōfukuji's Central Golden Hall (figure 2) and its East Golden Hall (figure 3), as both Ōwaki and Takahashi note. ${ }^{72}$ The Kōfukuji Central Golden Hall is widely believed to have once housed a Maitreya pure land tableau on the basis of written descriptions found in a text known as Kōfukuji ruki 興福寺流記. ${ }^{73}$ Although the text was

71 For a concise history of Kōfukuji in English, see Grapard, Protocol of the Gods, pp. 48-57. A recent publication on the history of Köfukuji is Bauer, "Tracing Yamashinadera."

72 Ōwaki, "Senbutsu to ryokuyū hamonsen ni yoru sōgon," p. 49; Takahashi, "Butsuzō sōgon toshiteno ryokuyū suihamonsen," pp. 127-28. In nn. 4 and 5 on p. 136, Takahashi lists the following with regard to the excavation history of the Köfukuji East Golden Hall wave-pattern fragments: Kokuhō Kōfukuji Higashi Kondō Shūri Jimusho, Kokuhō Kōfukuji Higashi Kondō shūri kōji hōkokusho; Kōfukuji, Kōfukuji bōsai shisetsu kōji. On the Central Golden Hall wave-pattern fragments, see Kōfukuji, Kōfukuji dai ikki keidai seibi jigyō ni tomonau hakkutsu chōsa gaihō ni, polychrome image on frontispiece, p. 14; and Nara Kokuritsu Bunkazai Kenkyūjo, "Kōfukuji Chū Kondō-in kairō no chōsa: Daizo8ji," SK 7560 on p. 36. This excavation report is available online at https://repository. nabunken.go.jp/dspace /bitstream/11177/5481/1/ANo0181387_2000_3_32 39.pdf

73 A color reproduction is available online at http://webarchives .tnm.jp/dlib/detail/3846;jsessionid=6F79DD5FC19ACD167369 $.047989462 \mathrm{FA} 2$. According to Grapard, Protocol of the Gods, 


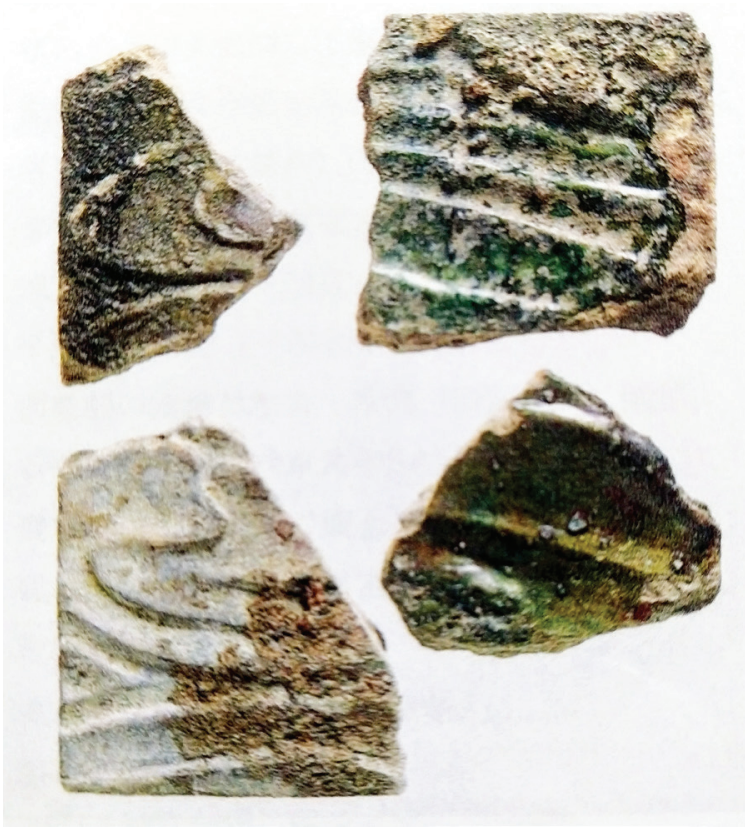

Figure 2. Wave-pattern tile excavated at Kōfukuji Central Golden Hall, Nara Prefecture. 8th c. D approx. 1.5 cm. From Kōfukuji, Kōfukuji dai ikki keidai seibi jigyō ni tomonau hakkutsu chōsa gaihō ni, p. 14, polychrome image on frontispiece; p. 14 for tile thickness. Permission of Kōfukuji.

compiled during the late Heian period, or several centuries after the presumed Maitreya tableau at Kōfukuji would have been dedicated, many scholars take what is recorded in Kōfukuji ruki at face value, not questioning the validity of its claims - mostly because additional evidence that could corroborate or refute such claims is unavailable..$^{74}$ According to the Hōjiki section in Kōfukuji ruki, Kōmyō's mother dedicated the Maitreya

n. 53 on p. 263, "The texts relating to the origins of the Kōfukuji are found in [DNBZ] where they are all collected under the title Kōfukuji sōsho [興福寺叢書; see pp. 295-307]. They include the Kōfukuji ruki, compiled toward the end of the Heian period ... [which] is itself made up of several documents: the Köfukuji engi [興福寺縁起] (dated 900); the Tempyō-ki [天平記], which covers the period 729-48; the Hojii-ki [寶字記] (757-64); the Enryaku-ki [延暦記] (782-806); the Kōnin-ki [弘仁記] (810-23); and other documents."

74 For a study in Japanese, see Shibuya, "Kōfukuji ruki ni tsuite." Shibuya investigates the reliability of Kōfukuji ruki, drawing attention to the different versions that were consulted and copied over several centuries. The original texts do not survive, but copies of earlier texts were repeatedly made-a process that introduced errors over time. According to Shibuya, some sections are more reliable than others, but caution is necessary because Köfukuji ruki is like a collection of remnants that were at times revised during replication.
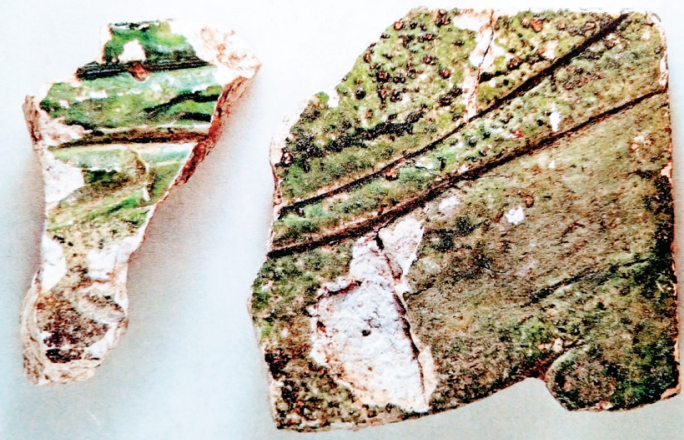

Figure 3. Wave-pattern tile excavated at Kōfukuji East Golden Hall, Nara Prefecture. 8th c. D 2.6-2.9 cm. From Kōfukuji, Kōfukuji bōsai shisetsu kōji, p. 49, polychrome image on frontispiece; p. 23 for tile thickness. Permission of Kōfukuji.

pure land tableau in Yōrō 養老 4 (720 CE) in memory of her husband, who had died that year. ${ }^{75}$ The relevant entry describes the details of the paradise scene: one Maitreya buddha; eight bodhisattvas; four arhats (rakan 羅漢); sixteen celestials (each holding a musical instrument according to written-in notes); twelve guardian figures; eight divinities (hachibu kami 八部神; possibly the Divinities of the Eight Classes, tenrȳ $\bar{u}$ hachibush $\bar{u}$ 天竜八部衆); two mythical or protector lions (shishi 獅子); what seems to be a censer for incense; various special trees; and two parrots or cockatoos (omu 鵙武). There is no mention of a pond or palace architecture in this entry but, as Takahashi notes, another entry that many scholars consider relevant does mention the use of glazed wave-pattern tiles. The entry appears in the section called Kyūsho anchi Miroku Jōdo engi 舊所安 置弥勒浄土縁起, whose title mentions "Maitreya pure land" (Miroku Jōdo 弥勒浄土), and it is here that we find the reference to ruri no den 瑠璃之殿. ${ }^{6}$ During this period, ruri meant both "glass" and "glazed" pottery, so this entry can be translated as "place/hall (den 殿) of glass/glazed ware (ruri 瑠璃).” Taken together this textual evidence seems to indicate the use of glazed tiles, presumably with wave patterns in line with the

75 DNBZ, pp. 297-98. Tōno Haruyuki revisits his analysis of the Kōfukuji Central Golden Hall and its icons in relation to Kōfukuji ruki in "Tenpyō jiin to bukkyō," p. 131; "Jōdai jiin no Kondō to sono dōnai kōsei," p. 77; and Yamato koji no kenkyū, pp. 11-14. See also Shibuya, "Kōfukuji ruki ni tsuite," pp. 58-59. 76 DNBZ, p. 298. 
archeological finds, in a hall featuring a Maitreya pure land tableau. ${ }^{77}$

A significant comparative visual source is a painting on silk, Kōfukuji mandarazu 興福寺曼荼羅図, which depicts the icons assembled inside most of Köfukuji's many buildings. ${ }^{7}$ In the painting, attributed to the twelfth century, the roof and walls of each structure (with the exception of the pagoda) were not depicted so as to reveal the icons and their raised platforms within..$^{79}$ Unfortunately, the floor and platform surfaces were left blank so it is not possible to confirm whether wave-patterned tiles were used there to depict a pond.

How accurate is the painting? We know that it was executed approximately four centuries after the Kōfukuji sculptures were installed in the temple's halls and that it contains obvious fictionalizations: Kasuga 春日 Shrine, for example, has been placed to the north of Köfukuji instead of to the east, its actual location. Further, the Kyoto National Museum monograph notes the presence of "touch ups" (hohitsu 補筆) made to the painting, which means what we now see in the painting is not the same as the original at the time of production. ${ }^{80}$ Putting aside these considerations, a comparison of the written description of the Maitreya pure land tableau inside the Kōfukuji Central Golden Hall and its painted image reveals a vague, superficial likeness with some differences. For example, according to the Kyoto National Museum monograph, the painting has only four (not eight) bodhisattvas ${ }^{81}$ and eighteen (not sixteen) celestials playing musical instruments. Whether these discrepancies are meaningful or not cannot be

77 Takahashi, "Butsuzō sōgon toshiteno ryokuyū suihamonsen," pp. 127-28. On p. 127, Takahashi writes that in Kōfukuji engi 興福寺 縁起 (compiled in Shoji engishū 諸寺縁起集, Gokokuji hon 護国 寺本), the term ruri appears in a note appended to a reference to what seems to be the Köfukuji East Golden Hall. Because wave-pattern tiles were also excavated in the vicinity of the East Golden Hall, the tiles may have been affixed inside both the East and Central Golden Halls at Kōfukuji. For this entry in Kōfukuji engi, see Fujita, Kōkan bijutsu shiryō, vol. 1, p. 270.

78 The painting is now in the Kyoto National Museum; for a reproduction, see https://www.kyohaku.go.jp/jp/syuzou/meihin /butsuga/item04.html. The painting's acquisition history and its relatively small dimensions $(96.8 \times 38.8 \mathrm{~cm})$ are provided in Kyoto National Museum, Kōfukuji mandarazu, p. 52.

79 The Kōfukuji Pagoda, considerably miniaturized in size, is depicted with exterior walls intact and obscures our view of what was housed inside the building.

80 Kyoto National Museum, Kōfukuji mandarazu, D2 on p. 68.

81 According to ibid., E15-E55 on pp. 70-71, there is a bodhisattva to the right and to the left of the Buddha, and a pair of dancing bodhisattvas near the bottom of the scene. known. But what seems to me most significant is how this tableau, despite what Kōfukuji ruki claims, could easily have been perceived as an Amitābha pure land tableau, especially since it was situated on the west end of the Central Golden Hall-a suitable location for Amitābha, the Buddha of the Western Paradise. In addition, the types of figures accompanying Maitreya in both the painting and the Köfukuji ruki description, such as the celestial musicians and guardians, are also associated with the imagery of Amitābha's pure land. Visual identification of this tableau as a Maitreya pure land, as opposed to an Amitābha pure land, seems nearly impossible and again reflects the notion of overlap in the representations of the two paradises. ${ }^{82}$

\section{Wave-Pattern Tiles from Tōdaiji and Hokkeji}

A number of eighth-century documents stored in Japanese temple collections serve as evidence that halls dedicated to Amitābha were indeed built at temple complexes in the ancient Nara capital. These halls are referred to by scholars today as Tōdaiji Amidadō 東大寺 阿弥陀堂 and Hokkeji Amida Jōdo-in 法華寺阿弥陀 浄土院 and will be discussed below. Specifically, the documents refer to rituals conducted in an Amitābha Hall (Amida-in 阿弥陀院), or list items used during such rituals, but none mention the name of the temple complex or the exact geographic location where the rituals were held. To locate the Amitābha halls described in the primary sources, scholars must interpret the material evidence, in particular the wave-pattern tile fragments unearthed at Tödaiji and Hokkeji. The task is made more difficult because some tile fragments have shifted from their original place of use due to either natural causes, such as mudslides, or manmade causes, such as digging or earth removal during construction. Many complicated arguments have been published, but here I offer a summary of recent developments. This section relies on the scholarship of Nakano Satoshi, whose work provides an extensive historiography and

82 Hayami compiled a list of entries from various primary documents related to the Maitreya cult dating from the seventh or eighth century in Japan. These express a range of aspirations; of special interest is an entry dated to 728-close in time to the purported Maitreya Pure Land tableau in the Köfukuji Central Golden Hall-in which the donor refers to both Maitreya and Amitābha and their respective paradises. Hayami, "Ritsuryō shakai ni okeru Miroku shinkō no juyō," entry 9 on p. 112. 
other useful background information..$^{83}$

A document stored at Tōdaiji, Amida kekaryō shi$z a i c h \bar{o}$ 阿弥陀悔過料資材帳, subtitled Amida-in hōmotsu mokuroku 阿弥陀院宝物目録, is a catalogue or inventory list related to the annual Amida Keka 阿弥陀 悔過 ritual, held during the third month in an "Amitābha Hall," which is named in the subtitle. ${ }^{84}$ Any details that would specify the location of this Amida-in are not recorded. If the document has always been stored at Tòdaiji, then it could very well be an internal record of a ritual conducted somewhere within the vast Tōdaiji complex. However, this document could have originated at another temple and was then transferred to Tōdaiji at some point.

Inscribed just below the subtitle is the date Jingo keiun gannen 神護景雲元年 $(767 \mathrm{CE})$, followed by a list of icons and scriptures; these were presumably used during the ritual at Amida-in. ${ }^{85}$ However, another inventory of icons and scriptures appears in the next section, at the end of which is an entry that reads "manufacture of the abovementioned [items] was completed in the third month of Tenpyō 13 [741 CE]." ${ }^{\text {86 }}$ This difference in time is critical: a record dating to 741 indicates the existence of an Amitābha Hall that predates the construction of Tòdaiji, which occurred after 745 , the year the capital was transferred back to Heijo (Nara) ${ }^{87}$ To account for this discrepancy, scholars have proposed two competing theories: either the Amida-in described in Amida kekaryō shizaichō belonged to an earlier temple built on the grounds of the Tòdaiji, or the Amida-in belonged to a different temple at a completely different site (Hokkeji is considered a leading candidate) and that temple's records were transferred to Tōdaiji at a later date. ${ }^{8}$ Excavations at both Tōdaiji and Hokkeji have yielded fragments of green-glazed wave-pattern tiles, which may have been used in an Amitabha Hall. It is important to remember, however, that wave-pattern tiles were apparently employed in a pure land tableau of Maitreya at Kōfukuji, so the recov-

83 Nakano, Nara jidai no Amida nyoraizō to Jōdo shinkō, pp. 83-121.

84 lbid., p. 83. For a reproduction of the text, see figure 24 on p. 84 ; for a modern reprint, see DNK Hennen 5, Jingo Keiun 神護景雲 1 (767).8.30 (pp. 671-83)

85 lbid., pp. 671-73.

86 DNK Hennen 5, Jingo Keiun 1 (767).8.30 (pp. 673-77).

87 Other explanations are possible; for instance, the two entries could be unrelated, or the inventories might refer to Amitābha rituals conducted at separate temples or at separate times.

88 Nakano, Nara jidai no Amida nyoraizō to Jōdo shinkō, p. 95. ery of wave-pattern tiles at Tōdaiji and Hokkeji does not serve as indisputable evidence of a lost Amitābha Hall. There could have been a Maitreya Hall instead, a possibility that is largely downplayed or neglected in the scholarship focused on identifying the Amitābha halls mentioned in written records.

Several of the green-glazed wave-pattern tile fragments from Tòdaiji were unearthed during the 1980s by Kashihara Kōkogaku Kenkyūjo 橿原考古学研究所 of Nara Prefecture; the pieces emerged while the group was excavating beneath Busshōya 仏飭屋, a small structure located near Nigatsudō 二月堂 and used as a special kitchen during the annual Omizutori お水取り ceremonies held in the first two weeks of the third month. ${ }^{89}$ Although the current Busshōya was built during the Kamakura period, artifacts found under the structure, including the wave-pattern tile fragments, date to the Nara and Heian periods (figure 4).${ }^{90}$ In the excavation report (1984), the lead archaeologist, Nakai Kazuo, proposed three stages of building activity at the site; the earliest stage was assigned to the first half of the eighth century, which predates the construction of Tōdaiji. Three decades later, Suzuki Kazuyoshi reexamined the excavation finds from Busshoyya and revised part of the earlier report. ${ }^{91}$ Instead of three stages, Suzuki proposed four stages of building activity at the site. Most significantly, Suzuki and his team located the earthenware vessel fragments catalogued from the excavation; their subsequent analysis of the vessel typology revealed the date of manufacture to be in the second half of the eighth century, not the first half as reported earlier. ${ }^{92}$ Details related to the proposed earliest structure and its building pattern also agree with this date, according to Suzuki. The corrected date indicates that the initial building activity at the Busshōya site does not predate Tōdaiji.

To further complicate the situation, Suzuki claims that roof tile fragments dating to the first half of the eighth century from the Busshōya excavation were not part of a structure built at this site, but instead had been moved there and may have originally been used

\footnotetext{
89 Naraken Bunkazai Hozon Jimusho, Jūyō bunkazai Tōdaiji Nigatsudō Busshōya shūri kōji hōkokusho.

$90 \mathrm{lbid} .$, p. 69. For a color reproduction, see the exhibition catalogue Nara National Museum, Tokubetsu chinretsu: Omizutori, p. 47. I am grateful to Hirooka Takanobu 廣岡孝信 for informing me about the catalogue.

91 Suzuki, "Tōdaiji Nigatsudō Busshōya kasō ikō no saikentō." 92 Ibid., pp. 375-76.
} 


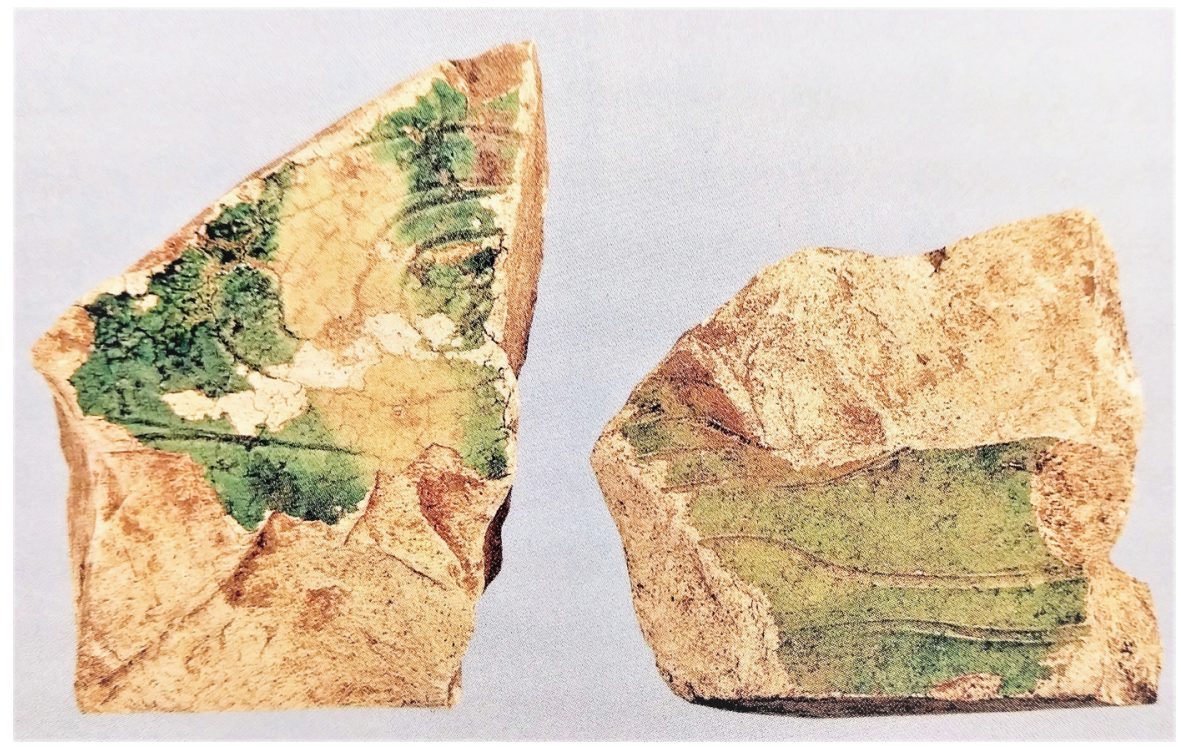

Figure 4. Wave-pattern tile excavated at Tōdaiji Busshōya of Nigatsudō, Nara Prefecture. 8th c. Right fragment: H 12.5, W 8.5 cm; left fragment: H 10.5, W $10.0 \mathrm{~cm}$. Housed at Tōdaiji. From Nara National Museum, Tokubetsu chinretsu: Omizutori, p. 47, fig. 32. Permission of Tōdaiji and Nara National Museum (photo by Morimura Kinji 森村欣司).

at a nearby temple that predates Tōdaiji, for instance Fukujuji 福寿寺, which is believed to have been built in this northern sector now occupied by Busshōya, Nigatsudō, and Sangatsudō 三月堂 (also known as Hokkedō 法華堂). ${ }^{93}$ Although a temple predating Tōdaiji could have existed near Busshōya, it was not situated at this exact location. Suzuki calls for further excavation to answer this and other questions about past building activity in this area. As for the wave-pattern tile fragments, their exact place and time of use remain unclear. Confirming such details is critical to pinpointing the location of a presumed pure land tableau or Amitābha Hall that once existed at what is now Tōdaiji.

We turn now to Hokkeji. Once a vast complex built just east of the former Heijō Palace in the capital, the temple today occupies a fraction of its original land holdings. The residential compound of Fujiwara Fuhito, mentioned above in connection with the history of Kōfukuji, was first constructed at this site. After his death, Fuhito's daughter Kōmyō established her Queen Consort Palace here and eventually transformed the site into the Hokkeji Buddhist temple complex. The Hokkeji Amida Jōdo-in is believed to have been situated to the south of the present temple. There is an ex-

93 Ibid., pp. 361, 379 tensive corpus of secondary analysis of Hokkeji's early history based on primary documents, even though the latter are rather vague in meaning. Here, instead of summarizing the analyses of written records concerning the relationship between Kōmyō, Hokkeji, and an Amitābha Hall, my focus is limited to a brief discussion of the relevant archaeological record. ${ }^{94}$

In 2000, Nara Kokuritsu Bunkazai Kenkyūjo excavated a small section of the southwest corner of Hokkeji, unearthing one fragment of a glazed wave-pattern tile (figure 5). The archaeologists presume the area was the former site of the Hokkeji Amida Jōdo-in. According to the report, the excavation also confirmed that a pond or small lake was made in the center of this area. There was an island in the pond with traces of three structures, perhaps a hall, bridge, or corridor, but the nature of the structures remains unclear. The report ends by noting that a pond was constructed at the Hokkeji Amida Jōdo-in in order to reflect Pure Land

94 A concise overview of the historiography concerning Hokkeji-related primary documents is found in Ōkusa, "Nara jidai Jōdo shinkōron no saikentō," pp. 230-36. A monograph devoted to Hokkeji Amida Jōdo-in is Sannomiya, Hokkeji Amida Jōdo-in to Byōdōin Hōōdō; see pp. 1-64 for a historiography and other background material regarding the proposed construction history of Hokkeji Amida Jōdo-in. 


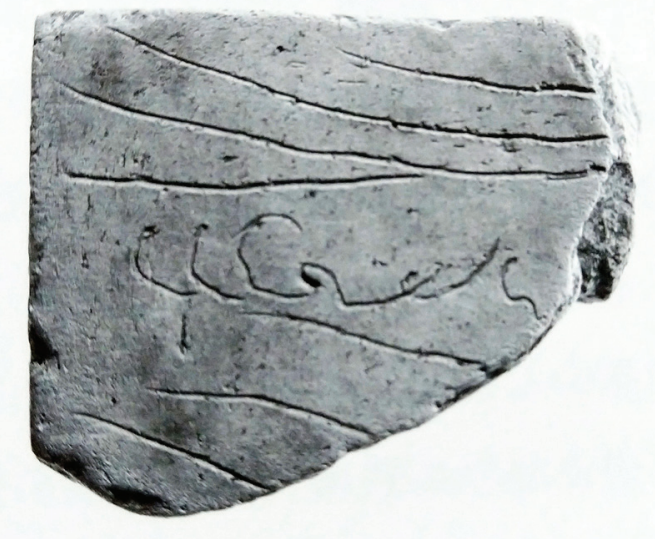

Figure 5. Wave-pattern tile excavated at Hokkeji, Nara Prefecture. 8th c. H 7.9, D 4.0 cm. From Nara Kokuritsu Bunkazai Kenkyūjo, "Hokkeji Jōdo-in no chōsa: Dai312ji," p. 60, fig. 66. Permission of Nara Bunkazai Kenkyūjo Asuka Shiryōkan.

ideology, in particular the conceptualization of a built environment that included both buildings and gardens as a unit. That is, the archaeologists suggest that the site is a Nara-period precursor to a type of built environment that became popular in the late Heian period, as can be seen at Byōdōin Hōōdō 平等院鳳凰堂 near Kyoto. ${ }^{95}$ These places included a lotus pond in front of palace buildings, offering an image of Sukhāvatī as a real place on earth.

\section{Concluding Remarks}

Evident in each of the studies presented in this research note is the strong desire on the part of scholars to reveal the exact nature of the early Amitābha cult in Japan. Yet making definitive assertions about the incipient stage of the Amitābha cult appears premature, especially since there seems to have been no independent Amitābha cult with consistent, standardized imagery during the seventh and eighth centuries in Japan, and likely through the ninth century. Instead, there were

95 Nara Kokuritsu Bunkazai Kenkyūjo, "Hokkeji Jōdo-in no chōsa: Dai312ji." A monochrome reproduction of the tile is available at http://repository.nabunken.go.jp/dspace/bitstream/11177/2754/1 /ANo0181387_2000_\%e2\%85\%a2_56_61.pdf (figure 66 on p. 60). One of the archaeologists involved in the excavation published a related article; see Watanabe, "Amida Jōdo-in to Kōmyōshi tsuizen jigyō." For another perspective, see Sannomiya, Hokkeji Amida Jōdo-in to Byōdōin Hōōdō, pp. 100-104. overlaps in use that were uneven and perhaps unorthodox. The notion of a heavenly pure land, a splendid paradise waiting for devotees after their death, was embraced and represented beginning in the Hakuhō and Nara periods, but specific questions concerning cultic practice may never be answered. Nevertheless, we should not forget that even if the life-size buddha icons dating to this period look generic and inaccessible to modern viewers because they lack inscriptions or do not strictly adhere to a known or standardized iconography, they were undoubtedly sponsored by patrons who gave them precise identities in order to gain specific merit.

\section{Reference List}

\section{- Abbreviations Used}

DNBZ Dai Nihon bukkyō zensho 大日本仏教全書. Vol. 84, ed. Suzuki Gakujutsu Zaidan 鈴木学術財団. Kōdansha, 1972.

DNK Hennen Dai Nihon komonjo: Hennen monjo 大日本古文書: 編年文書. Ed. Tōkyō Daigaku Shiryō Hensanjo 東京大学史料編纂所. 25 vols. Tōkyō Daigaku Shuppankai, 1901-1940.

NBZ Nihon bijutsu zenshū日本美術全集. Ed. Mizuno Keisaburō 水野敬三郎 et al. 25 vols. Kōdansha, 1990-1994.

T Taishō shinshū daizōkyō 大正新脩大藏經. 100 vols. Ed. Takakusu Junjirō 高楠順次郎 and Watanabe Kaigyoku 渡邊海旭 et al. Taishō Issaikyō Kankōkai, 1924-1934. Digitized in CBETA (v. 5.2) and SAT Daizōkyō Text Database (https://21dzk.l.u-tokyo.ac.jp/SAT/index.html).

\section{- Primary and Secondary Sources}

Bauer, Mikael. "Tracing Yamashinadera." Journal of Asian Humanities at Kyushu University 5 (2020), pp. 17-28.

Bogel, Cynthea J. With a Single Glance: Buddhist Icon and Early Mikkyō Vision. University of Washington Press, 2009.

Copp, Paul. The Body Incantatory: Spells and the Ritual Imagination in Medieval Chinese Buddhism. Columbia University Press, 2014. 
Darani jikkyō 羅尼集経 (Ch. Tuoluoni jijing). [See Foshuo Tuoluoni jijing fanyi $x u$.]

Foshuo Guan wuliangshoufo jing 仏説観無量寿仏経. T 365 12:340c-346b.

Foshuo Tuoluoni jijing fanyi $x u$ 佛説陀羅尼集経翻譯序. T 901 18:785a-804c.

Fujita Kōtatsu 藤田宏達. Jōdo sanbukyō no kenkyū 浄土 三部経の研究. Iwanami Shoten, 2007.

Fujita Tsuneyo 藤田經世, ed. Kōkan bijutsu shiryō 校刊美術 史料. 3 vols. Chūō Kōron Bijutsu Shuppan, 1972-1976.

Gómez, Luis O., trans. "Rebirth in the Land of Bliss." In Buddhist Scriptures, ed. Donald S. Lopez Jr., pp. 6o-68. London: Penguin Books, 2004.

Gómez, Luis O., trans. The Land of Bliss, The Paradise of the Buddha of Measureless Light: Sanskrit and Chinese Versions of the Sukhāvatīvyūha Sutras. University of Hawai'i Press; Kyoto: Higashi Honganji Shinshū Ōtani-ha, 1996.

Grapard, Allan. Protocol of the Gods: A Study of the Kasuga Cult in Japanese History. University of California Press, 1993.

Hayami Tasuku 速水侑. “Ritsuryō shakai ni okeru Miroku shinkō no juyō” 律令社会における弥勒信仰の受容. In Miroku shinkō 弥勒信仰, ed. Miyata Noboru 宮田登, pp. 109-30. Vol. 8 of Minshū shūkyōshi sōsho 民衆宗教史 叢書. Yūzankaku Shuppan, 1984.

Hida Romi 肥田路美. “Ōgata tason senbutsu to Hōryūji Kondō hekiga” 大型多尊塼仏と法隆寺金堂壁画. In Kodai jiin no geijutsu sekai 古代寺院の芸術世界, ed. Hida Romi, pp. 386-413. Vol. 6 of Kodai bungaku to rinsetsu shogaku 古代文学と隣接諸学. Chikurinsha, 2019.

Hsu, Eileen Hsiang-ling. "The Sengchou Cave and Early Imagery of Sukhāvatī." Artibus Asiae 71:2 (2011), pp. 283-323.

Inagaki, Hisao, trans. The Three Pure Land Sutras. BDK America, Inc., (2003) 2017.

Ishida Mosaku 石田茂作. Shakyō yori mitaru Narachō bukkyō no kenkyū 写経より見たる奈良朝仏教の研究. Tōyō Bunko, 1930.

Kōfukuji 興福寺. Kōfukuji bōsai shisetsu kōji, Hakkutsu chōsa hōkokusho 興福寺防災施設工事・発掘調査 報告書. 1978 .

Kōfukuji. Kōfukuji dai ikki keidai seibi jigyō ni tomonau hakkutsu chōsa gaihō ni 興福寺第1期境内整備事業に ともなう発掘調査概報 II. 2000.

Kokuhō Kōfukuji Higashi Kondō Shūri Jimusho 國寶興福寺 東金堂修理事務所. Kokuhō Kōfukuji Higashi Kondō shūri kōji hōkokusho 國寶興福寺東金堂修理工事報告書. 1940.

Kyoto National Museum. Kōfukji mandarazu 興福寺 曼荼羅図. 1995

Lee, Sonya. Surviving Nirvana: Death of the Buddha in Chinese Visual Culture. Hong Kong University Press, 2010.

Lowe, Bryan. Ritualized Writing: Buddhist Practice and Scriptural Cultures in Ancient Japan. University of Hawai' $i$ Press/Kuroda Institute, 2017.

Matsunaga, Alice, and Daigan Matsunaga. Foundation of Japanese Buddhism. 2 vols. Los Angeles and Tokyo: Buddhist Books International, (1976) 1993.

McCallum, Donald. Hakuhō Sculpture. Spencer Museum of Art at The University of Kansas; University of Washington Press, 2012.

McCallum, Donald. The Four Great Temples: Buddhist Archaeology, Architecture, and Icons of Seventh-Century Japan. University of Hawai'i Press, 2009.

Mitsumori Masashi 光森正士. Amida nyoraizō 阿弥陀 如来像. Nihon no bijutsu 日本の美術 241 (1986).

Mizuno Keisaburō 水野敬三郎. “Amida sanzonzō Denpōdō Nishinoma shozai” 阿弥陀三尊像伝法堂西の間所在. In vol. 3 of Nara rokudaiji taikan: Hōryūji 奈良六大寺大 観: 法隆寺, ed. Nara Rokudaiji Taikan Kankōkai 奈良六 大寺大観刊行会, pp. 64-71. Iwanami Shoten, 1969.

Mizuno Keisaburō. "Hōryūji Denpōdō no Amida sanzonzō sangu” 法隆寺伝法堂の阿弥陀三尊像三具. In Nihon chōkokushi kenkyū 日本彫刻史研究, pp. 121-34. Chūō Kōron Bijutsu Shuppan, 1996.

Mizuno Saya 水野さや. “Hachibushūzō no seiritsu to hirogari”八部衆像の成立と広がり. In Sei naru mono no katachi to ba 聖なるものの形と場, ed. Yoritomi Motohiro 頼富本宏, pp. 197-222. Kyoto: Hōzōkan, 2004.

Muryōjukyō 無量寿経 (Ch. Wuliangshou jing). T 360 12:265c-279a.

Nagaoka Ryūsaku 長岡龍作. “Amida zuyō no keishō to saisei: Kōmyō kōgō gosaie Amida nyoraizō o megutte" 阿弥陀図様の継承と再生: 光明皇后御斎会阿弥陀如 来像をめぐって. In Bunka shi no kōsō 文化史の構想, ed. Ōsumi Kazuo 大隅和雄, pp. 272-30o. Yoshikawa Kōbunkan, 2003.

Nakagawa Fumi 中川二美. “Hokkeji kyūkeidai shutsudo kokusenmon nisaisen ni tsuite” 法華寺旧境内出土刻線 文二彩磚について. Nara Bunkazai Kenkyūjo kiyō 奈良 文化財研究所紀要 (2015), pp. 58-59.

Nakano Satoshi 中野聡. Nara jidai no Amida nyoraizō to Jōdo shinkō 奈良時代の阿弥陀如来像と浄土信仰. Bensei Shuppan, 2013. 
Nara Kokuritsu Bunkazai Kenkyūjo 奈良国立文化財研究所. “Hokkeji Jōdo-in no chōsa: Dai312ji” 法華寺浄土院の 調査: 第312次. In Nara Kokuritsu Bunkazai Kenkyūjo $n e n p \bar{o}$ 奈良国立文化財研究所年報 2000-III, pp. 56-61. 2000.

Nara Kokuritsu Bunkazai Kenkyūjo. "Kōfukuji Chū Kondō-in kairō no chōsa: Daizo8ji” 興福寺中金堂院 回廊の調査: 第308次. In Nara Kokuritsu Bunkazai Kenkyūjo nenpō 200o-III, pp. 32-39. 2000.

Nara Kokuritsu Bunkazai Kenkyūjo. Shiseki Zutō hakkutsu chōsa hōkoku 史跡頭塔発掘調査報告. Vol. 62 of Nara Kokuritsu Bunkazai Kenkyūjo gakuhō 奈良国立文化財 研究所学報. 2001.

Nara National Museum. Tokubetsu chinretsu: Omizutori 特別陳列: お水取り. 2001.

Naraken Bunkazai Hozon Jimusho 奈良県文化財保存事務所, ed. Jūyō bunkazai Tōdaiji Nigatsudō Busshōya shūri kōji hōkokusho 重要文化財東大寺二月堂仏餉屋修理工事 報告書. Naraken Kyōiku Ii’nkai, 1984.

Okada Ken 岡田健. “Shotōki no Tenpōrin'in Amida zuzō ni tsuite no kenkyū” 初唐期の転法輪印阿弥陀図像につい ての研究. Bijutsu kenkyū 美術研究 373 (2000), pp. 1-48.

Ōkusa Hiroshi 大忡啓. “Nara jidai Jōdo shinkōron no saikentō” 奈良時代浄土信仰論の再検討. Shinshū kenkyu 眞宗研究 59 (2015), pp. 229-54.

Orzech, Charles. "Ritual Subjects: Homa in Chinese Translations and Manuals from the Sixth to the Eighth Centuries." In Homa Variations: The Study of Ritual Change across the Longue Durée, ed. Richard Payne and Michael Witzel, pp. 266-87. Oxford University Press, 2016.

Ōta Hidezō 太田英蔵. “Tsuzure ori Taima mandara ni tsuite” 綴織当麻曼荼羅について. In Kokuhō tsuzure ori Taima mandara 国宝綴織当麻曼荼羅, ed. Bunkazai Hogo Ii’nkai 文化財保護委員会. Benridō, 1963.

Ōta Hidezō. “Tsuzure ori Taima mandara ni tsuite.” In Kokuhō tsuzure ori Taima mandara, ed. Tanaka Ichimatsu 田中一松 and Tatsumura Heizō 龍村平蔵, pp. 73-81. Kōsei Shuppansha, 1978.

Ōwaki Kiyoshi 大脇潔. “Dōnai sōgon no kōkogaku: Ryokuyū hamonsen to senbutsu kara” 堂内荘㛜の考古学: 緑釉波紋塼と塼仏から. In Kodai jiinshi no kenkyū 古代寺院史の研究, ed. Hishida Tetsuo 菱田哲郎 and Yoshikawa Shinji 吉川真司, pp. 17-35. Shibunkaku Shuppan, 2019.

Ōwaki Kiyoshi. “Kawaradera” 川原寺. In Asuka no tera 飛鳥の寺, vol. 14 of Nihon no koji bijutsu 日本の古寺美術, pp. 102-37. Hoikusha, 1989.
Ōwaki Kiyoshi. "Senbutsu to ryokuyū hamonsen ni yoru sōgon: Yamadadera to Kawaradera, Tachibanadera” 塼仏と緑釉波紋塼による荘厳: 山田寺と川原寺·橘寺. In Hajimari no mihotoketachi はじまりの御仏たち, pp. 42-51 and color plates pp. 6-16; 23. Exhibition catalogue no. 62. Nara Kokuritsu Bunkazai Kenkyūjo, Asuka Shiryōkan, 2015.

Payne, Richard, and Kenneth Tanaka, eds. Approaching the Land of Bliss: Religious Praxis in the Cult of Amitäbha. University of Hawai'i Press/Kuroda Institute, 2004.

Rhodes, Robert. "The Beginning of Pure Land Buddhism in Japan: From Its Introduction through the Nara Period." Japanese Religions 31:1 (2006), pp. 1-22.

Sannomiya Chika 三宮千佳. Hokkeji Amida Jōdo-in to Byōdōin Hōōdō 法華寺阿弥陀浄土院と平等院鳳凰堂. Bensei Shuppan, 2014.

Sawa Ryūken 佐和隆研. “Darani jikkyō oboegaki” 陀羅尼集経 覚書. Bukkyō geijutsu 仏教芸術 100 (1975), pp. 53-58.

Scharf, Robert. “On Pure Land Buddhism and Ch'an/Pure Land Syncretism in Medieval China." T'oung Pao 88 (2002), pp. 282-331.

Schopen, Gregory. "Sukhāvatī as a Generalized Religious Goal." In Figments and Fragments of Mahāyāna Buddhism in India: More Collected Papers, pp. 154-89. University of Hawai'i Press, 2005.

Schopen, Gregory. “The Inscription on the Kuṣān Image of Amitābha and the Character of the Early Mahāyāna in India." In Figments and Fragments of Mahāyāna Buddhism in India: More Collected Papers, pp. 247-77. University of Hawai'i Press, 2005.

Seyama Satoshi 瀬山里志. “Darani jikkyō yō Shitennōzō no Nihon ni okeru juyō to tenkai” 陀羅尼集経様四天王像 の日本における受容と展開. Bukkyō geijutsu 239 (1998), pp. 73-93.

Shibuya Wakiko 涉谷和貴子. “Kōfukuji ruki ni tsuite” 『興福寺流記』について. Bukkyō geijutsu 160 (1985), pp. 49-62.

Shinohara, Koichi. Spells, Images, and Mandalas: Tracing the Evolution of Esoteric Buddhist Rituals. Columbia University Press, 2014.

Shirai, Yoko Hsueh. “The Amitābha Senbutsu Unearthed in Japan: Close Interactions with Unified Silla Korea in the Late Seventh Century." Artibus Asiae 74:1 (2014), pp. 163-90.

Shirai, Yoko Hsueh. "The Buddha Triad Senbutsu Unearthed in Japan: Replicating and Reinventing the Chinese Prototype in the Seventh Century." Artibus Asiae 71:2 (2011), pp. 185-219. 
Steinhardt, Nancy. "Xiangtangshan and Northern Qi Architecture." In Tsiang, Echoes of the Past, pp. 59-77.

Suzuki Kazuyoshi 鈴木一議. “Tōdaiji Nigatsudō Busshōya kasō ikō no saikentō” 東大寺二月堂仏館屋下層遺構の再 検討. In Tōdaiji no bijutsu to kōko 東大寺の美術と考古, ed. Sakaehara Towao 栄原永遠男, pp. 361-83. Kyoto: Hōzōkan, 2016.

Takahashi Teruhiko 高橋照彦. “Butsuzō sōgon toshiteno ryokuyū suihamonsen” 仏像荘㛜としての緑釉水波文塼. In Nihon jōdai ni okeru butsuzō no sōgon 日本上代における 仏像の荘㛜, ed. Washizuka Hiromitsu 熟塚泰光, pp. 127-37. Nara National Museum, 2003.

Takahashi Teruhiko. “Sansai, ryokuyūsen sairon” 三彩·緑釉 塼再論. In Kodai jiinshi no kenkyū, ed. Hishida Tetsuo and Yoshikawa Shinji, pp. 37-54. Shibunkaku Shuppan, 2019.

Ten Grotenhuis, Elizabeth. Japanese Mandalas: Representations of Sacred Geography. University of Hawai'i Press, 1999.

Tōno Haruyuki 東野治之. “Jōdai jiin no Kondō to sono dōnai kōsei”上代寺院の金堂とその堂内構成. In Nihon jōdai ni okeru butsuzō no sōgon, ed. Washizuka Hiromitsu, pp. 73-78. Nara National Museum, 2003.

Tōno Haruyuki. “Tenpyō jiin to bukkyō” 天平寺院と仏教. In Kodai o kangaeru: Nara 古代を考える: 奈良, ed. Naoki Kōjirō 直木孝次郎, pp. 130-38. Yoshikawa Kōbunkan, 1985.

Tōno Haruyuki. Yamato koji no kenkyū 大和古寺の研究. Hanawa Shobō, 2011.

Tsiang, Katherine, ed. Echoes of the Past: The Buddhist Cave Temples of Xiangtangshan. Smart Museum of Art at the University of Chicago, 2010.

Watanabe Akihiro 渡辺晃宏. “Amida Jōdo-in to Kōmyōshi tsuizen jigyō” 阿弥陀浄土院と光明子追善事業. Nara shigaku 奈良史学 18 (2000), pp. 30-41. 